\title{
Electrochemical Deprotection of para-Methoxybenzyl Ethers in a Flow Electrolysis Cell
}

\author{
Robert A. Green, ${ }^{\dagger}$ Katherine E. Jolley, ${ }^{\dagger}$ Azzam A. M. Al-Hadedi, ${ }^{\dagger}$ Derek Pletcher, ${ }^{\dagger}$ David C. Har- \\ rowven, ${ }^{\dagger}$ Oscar De Frutos, ${ }^{\star}$ Carlos Mateos,${ }^{\ddagger}$ David J. Klauber ${ }^{\S}$ Juan A. Rincón,${ }^{\star}$ Richard C. D. \\ Brown* ${ }^{\dagger}$
}

${ }^{\dagger}$ Department of Chemistry, University of Southampton, Southampton, Hampshire SO17 1BJ, U.K.

* Centro de Investigación Lilly S.A., Avda. de la Industria 30, 28108 Alcobendas-Madrid, Spain

${ }^{\S}$ Early Chemical Development, AstraZeneca, Charter Way, Macclesfield, SK10 2NA, U.K.

Supporting Information Placeholder

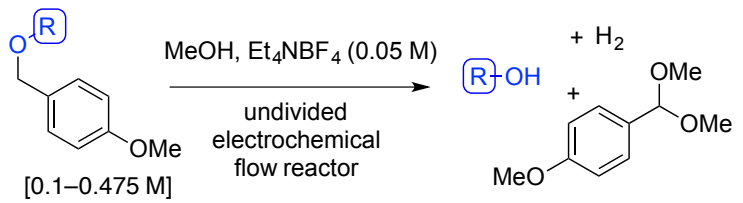

- Reagent free anodic deprotection of PMB ethers in flow
- 17 Examples (up to $93 \%$ ) and up to $55.5 \mathrm{mmol} \mathrm{h}^{-1}$

- 17 Examples (up to $93 \%$ ) and up to
- Electrolyte recovered and re-used

ABSTRACT: Electrochemical deprotection of $p$-methoxybenzyl (PMB) ethers was performed in an undivided electrochemical flow reactor in $\mathrm{MeOH}$ solution, leading to the unmasked alcohol and $p$-methoxybenzaldehyde dimethyl acetal as byproduct. The electrochemical method removes the need for chemical oxidants, and added electrolyte $\left(\mathrm{BF}_{4} \mathrm{NEt}_{4}\right)$ can be recovered and reused. The method was applied to 17 substrates with high conversions in a single pass, yields up to $93 \%$ and up to $7.5 \mathrm{~g} \mathrm{~h}^{-1}$ productivity. The PMB protecting group was also selectively removed in the presence of some other common alcohol protecting groups.

The use of protecting groups is common during multi-step syntheses of target molecules of even moderate complexity, adding reaction steps and reducing atom economy. ${ }^{2}$ Yet, without protecting groups the scope of application of many synthetic methods would be greatly compromised. Although efforts to avoid protecting groups or to combine their introduction and/or removal with other chemical transformations have had some success, ${ }^{3}$ for now the use of protecting groups seems inevitable. Therefore, the development of more sustainable deprotection methods is a worthy line of investigation, particularly where the ultimate objective will involve scale up.

The $p$-methoxybenzyl (PMB), or $p$-methoxyphenylmethyl (MPM), group is a well known protecting group used to mask the reactivity of alcohols in multi-step synthesis. ${ }^{1,4}$ PMB protection of carboxylic acids and nitrogen-containing compounds can also be useful. ${ }^{5}$ Typical conditions for cleavage of PMB ethers employ stoichiometric excesses of DDQ or CAN (Scheme 1), ${ }^{6}$ but various other deprotection methods have been reported. $^{1 a, 7,8}$ PMB ethers are frequently employed in situations where a benzyl-type protecting group is desirable, but other functionality present in the substrate are incompatible with removal by hydrogenolysis or dissolving metal conditions. On the other hand, PMB and benzyl ethers can be used together in orthogonal protecting group strategies. ${ }^{9}$

Scheme 1. Examples of Deprotections of PMB Ethers
Typical PMB deprotection

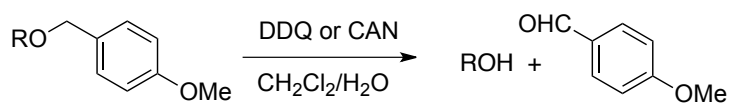

Electrochemical deprotection (direct)

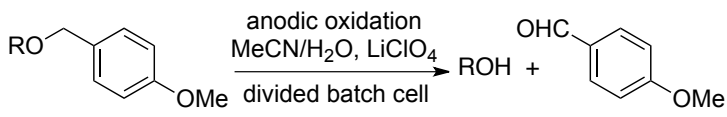

Electrochemical deprotection (mediated) anodic oxidation

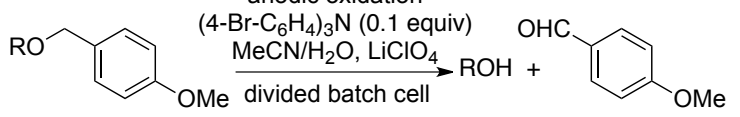

Benzylic oxidation is very well known in the electrochemical literature, with the oxidation of $p$-tert-butyltoluene to $p$ tert-butylbenzaldehyde performed on an industrial scale. ${ }^{10}$ Electrosynthesis offers an opportunity for substantial reduction in the waste associated with PMB deprotection, by removing the need for chemical oxidants completely or allowing catalytic loadings of a mediator. In 1974 Weinreb reported direct electrochemical deprotection of PMB ethers using a divided batch cell (Scheme 1), while in 1978 Streckhan reported the use of tris( $p$-bromophenyl)amine as an electrochemical mediator to cleave PMB and benzyl protected alcohols, also in a 
divided batch cell. ${ }^{11}$ Microfluidic electrolysis cells offer some advantages over batch reactors, such as favorable electrode area to reactor volume, improved control over heat transfer and ease of scale-up by extending the period of operation. ${ }^{12}$ Furthermore, narrow interelectrode gaps allow reduced amounts of electrolyte to be used. ${ }^{13}$ Recently, we described extended path microflow electrolysis reactors for laboratory synthesis on $100 \mathrm{mg}$ to $100 \mathrm{~g}$ scales, which are designed to achieve high conversion in one pass. ${ }^{14}$ Here we report their application in reagent free anodic cleavage of PMB ethers.

The electrochemical deprotection of PMB ether 1 was selected for initial optimization using an undivided cell containing an extended spiral flow channel (length: $1000 \mathrm{~mm}$, width: $2 \mathrm{~mm}$, interelectrode gap: $0.5 \mathrm{~mm}$ ) formed by a perfluoroelastomer spacer separating a carbon/PVDF anode and a stainless steel cathode. ${ }^{14 \mathrm{a}} \mathrm{MeOH}$ and $\mathrm{H}_{2} \mathrm{O}$ were considered to be suitable solvents, functioning as nucleophilic traps for the benzylic cations produced at the anode, while also providing useful cathode counter electrode reactions, where formation of methoxide or hydroxide and $\mathrm{H}_{2}$ counteracts build-up of $\mathrm{H}^{+}$in the flow channel. Formation of gas bubbles may also increase turbulence and improve reactor performance. ${ }^{15}$

Table 1. Optimization of Electrochemical Deprotection ${ }^{\text {a }}$

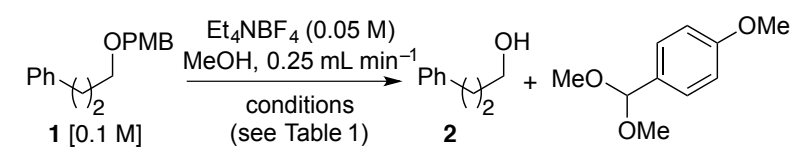

\begin{tabular}{|c|c|c|c|c|}
\hline entry & $\begin{array}{l}\text { current } \\
(\mathrm{mA})\end{array}$ & $\begin{array}{l}\text { cell voltage } \\
\text { (V) }\end{array}$ & $\begin{array}{l}\text { current effi- } \\
\text { ciency }(\%)\end{array}$ & yield $^{\mathrm{b}}(\%)$ \\
\hline 1 & 80 & 3.4 & 79 & 79 \\
\hline 2 & 100 & 3.3 & 68 & 84 \\
\hline 3 & 120 & 3.4 & 58 & 87 \\
\hline 4 & 135 & 3.5 & 55 & 92 \\
\hline 5 & 160 & 3.7 & 41 & 82 \\
\hline 6 & 135 & 3.6 & 45 & $75^{\mathrm{c}}$ \\
\hline 7 & 135 & 5.5 & 49 & $82^{\mathrm{d}}$ \\
\hline 8 & 135 & 3.4 & 30 & $51^{\mathrm{e}}$ \\
\hline 9 & 135 & 3.0 & 8 & $13^{\mathrm{f}}$ \\
\hline
\end{tabular}

${ }^{\text {a }}$ Reactions performed on a $0.5 \mathrm{mmol}$ scale $(5.0 \mathrm{~mL})$ in the Ammonite 8 electrochemical flow reactor. ${ }^{\mathrm{b}}$ Yield determined using calibrated GC. ${ }^{\mathrm{c}}$ Reaction solvent was $\mathrm{MeOH} / \mathrm{H}_{2} \mathrm{O}$ (10:1); byproduct was 4-methoxybenzaldehyde. ${ }^{\mathrm{d}}$ Reduced electrolyte $(0.005 \mathrm{M}) .{ }^{\mathrm{e}}$ Electrolyte was $\mathrm{NaBF}_{4}(0.05 \mathrm{M}) .{ }^{\mathrm{f}}$ Pt electrode.

A general electrochemical deprotection protocol was established for the PMB ether 1, using a $0.10 \mathrm{M} \mathrm{MeOH}$ solution, containing $\mathrm{Et}_{4} \mathrm{NBF}_{4}(0.05 \mathrm{M})$ as added electrolyte, at a flow rate of $0.25 \mathrm{~mL} \mathrm{~min}^{-1}$. It is important to recognize that sufficient current is needed to drive the desired chemical change, ${ }^{15}$ and electrolysis conditions were optimized to achieve full conversion, which requires at least $80 \mathrm{~mA}$ under conditions of mass transfer control. In practice, a scan of currents of 80-135 $\mathrm{mA}$ (Table 1, entries 1-4) revealed conversions in the range 94-100\%, with the highest yield of 2 obtained at $135 \mathrm{~mA}$ (entry 4). Increasing the current further (entry 5) led to a reduction in yield due to over oxidation. The results in $\mathrm{MeOH}$ alone were superior in comparison to $\mathrm{MeOH} / \mathrm{H}_{2} \mathrm{O}(10: 1)$ mixtures (entry 6). Reducing the amount of electrolyte $\left(\mathrm{Et}_{4} \mathrm{NBF}_{4}\right)$ to $0.005 \mathrm{M}$ (entry 7) gave a modest decrease in yield of 2 , and expected increase in cell voltage due to the more poorly conducting medium. Changing electrolyte to $\mathrm{NaBF}_{4}$ or anode material to Pt (sheet, $0.1 \mathrm{~mm}$ thickness, 99.9\%), both resulted in substantial reductions in yield. It is noteworthy that the $\mathrm{Et}_{4} \mathrm{NBF}_{4}$ is conveniently recovered from the crude reaction mixture by trituration with EtOAc, and can be recrystallized and reused over many electrosyntheses.

\section{Table 2. Electrochemical Cleavage of PMB Ethers ${ }^{\text {a }}$}

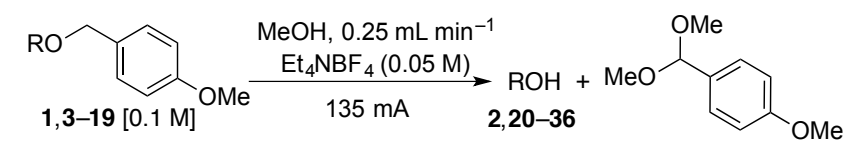

$\begin{array}{lllll}\text { entry } & \begin{array}{l}\text { product, } \\ \text { yield } \\ (\%)\end{array} & \begin{array}{l}\text { current } \\ \text { efficien- } \\ \text { cy }(\%)\end{array} & \begin{array}{l}\text { productivity } \\ \left(\mathrm{mg} \mathrm{h}^{-1}\right)\end{array} \\ \left.\mathrm{mmol} \mathrm{h}^{-1}\right\}\end{array}$

${ }^{\text {a }}$ Reactions performed in the Ammonite 8 electrochemical flow reactor, fitted with a C/PVDF anode and stainless steel cathode. All reactions conducted on $0.50 \mathrm{mmol}$ scale $(20 \mathrm{~min}$ run time with $5 \mathrm{~mL}$ total volume). ${ }^{\mathrm{b}}$ Isolated yield. ${ }^{\mathrm{c}}$ GC yield. ${ }^{\mathrm{d}}$ Reaction per- 
formed at $80 \mathrm{~mA} .{ }^{\mathrm{e}}$ Yield based on recovered 12. ${ }^{\mathrm{f}}$ Reaction performed at $70 \mathrm{~mA} .{ }^{\mathrm{g}} 18 \%$ yield of diol product was also obtained.

The conditions established for anodic deprotection of PMB ether 1 proved to be effective for a range of substrates containing unsaturation and sulfonyl functionality (Table 2, entries 3 and 4), a protected sugar derivative (entry 6) and examples of saturated and unsaturated nitrogen heterocycles (entries 7-10). Selective cleavage of the PMB ether was generally achieved, including examples where oxidizable nitrogen functional groups were present (entries 8-11). For PMB deprotection of Boc-protected amines $\mathbf{1 0}$ and $\mathbf{1 2}$ a reduced current of $80 \mathrm{~mA}$ was used to avoid oxidation $\alpha$ to the nitrogen functionality (entries 9 and 11). ${ }^{16}$ Piperazine and tosyl-protected piperidine substrates, 9 and 11 (entries 8 and 10), were deprotected without over-oxidation under the higher current conditions.

Anodic cleavage of the PMB group was also achieved in the presence of other common alcohol protecting groups, including OTHP, OAc, OTBDPS, OTBS and OBn. Notably, PMB ethers of diols protected with TBS or THP groups at the primary alcohol positions proved to be more sensitive to the deprotection conditions, and the TBS ethers $\mathbf{1 5}$ and $\mathbf{1 8}$ afforded fully deprotected diols as the major products at $135 \mathrm{~mA}$ (entries 12,14, 17 and 18). Selective removal of the PMB ether group was achieved by reducing the cell current to 70 $\mathrm{mA}$ giving improved yields of the PMB deprotected products (entries 14 and 17). It is possible that increased local acidity in the proximity of the anode, a consequence of oxidation of the PMB group, may catalyze cleavage of the more acid sensitive silyl ether functionality.

Current efficiencies for electrochemical deprotection in flow were $\sim 50 \%$ for most of the examples studied, which is expected under conditions of excess current. This is due to oxidation of the solvent and formation of minor unidentified byproducts. Significant over oxidation was only observed for the N-Boc derivatives $\mathbf{1 0}$ and $\mathbf{1 2}$, but the methoxylated byproducts were minimized at lower current. It is emphasized, however, that the conditions have been optimized to favor high conversion rather than high current efficiency, and the cost of electricity is not important on a laboratory scale, and considerably less than common oxidizing agents.

Table 3. Scale up of Electrochemical Deprotection in Flow

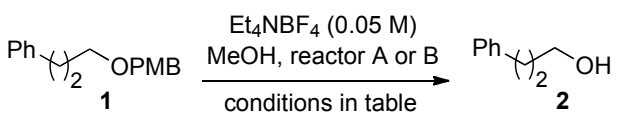

\begin{tabular}{|c|c|c|c|c|c|}
\hline entry & $\begin{array}{l}\text { conc. } \\
\mathbf{1}(\mathrm{M})\end{array}$ & $\begin{array}{l}\text { flow rate } \\
\left(\mathrm{mL} \mathrm{min}^{-1}\right)\end{array}$ & $\begin{array}{l}\text { current } \\
\text { (A) }\end{array}$ & $\begin{array}{l}\text { yield }^{a} \\
(\%)\end{array}$ & $\begin{array}{l}\text { productivi- } \\
\text { ty }\left(\mathrm{g} \mathrm{h}^{-1}\right)\end{array}$ \\
\hline $1^{\mathrm{b}}$ & 0.475 & 0.25 & 0.65 & 89 & $0.86^{\mathrm{d}}$ \\
\hline $2^{c}$ & 0.30 & 4.00 & 6.00 & 77 & $7.6^{\mathrm{e}}$ \\
\hline
\end{tabular}

${ }^{\mathrm{a}}$ Isolated yield. ${ }^{\mathrm{b}}$ Ammonite 8 electrochemical flow reactor (A). ${ }^{\mathrm{c}}$ Ammonite 15 electrochemical flow reactor (B). ${ }^{\mathrm{d}} 6.3 \mathrm{mmol}$ $\mathrm{h}^{-1}$. e $55.5 \mathrm{mmol} \mathrm{h}^{-1}$

Table 4. Comparison of Selected Sustainability Metrics for PMB Ether Deprotection Reactions ${ }^{16}$

\begin{tabular}{|c|c|c|c|c|c|c|}
\hline entry & reaction and conditions & $\begin{array}{l}\text { yield } \\
(\%)\end{array}$ & $\begin{array}{l}\text { scale } \\
(\mathrm{g})\end{array}$ & $\begin{array}{l}\text { atom econ- } \\
\text { omy }(\%)\end{array}$ & $\begin{array}{l}\text { reaction mass } \\
\text { efficiency }(\%)\end{array}$ & $\begin{array}{l}\text { hazardous or pre- solvents } \\
\text { cious chemicals }\end{array}$ \\
\hline
\end{tabular}

A benefit of electrosynthesis in flow is the ability to quickly scale up the reaction by: a) increasing the flow rate, b) increasing the concentration or $\mathrm{c}$ ) increasing the volume of the reaction solution. To demonstrate the ease of laboratory scale up the deprotection of 1, generating 2, was investigated at higher concentration and flow rate, over a longer duration (table 3 ). Increasing the concentration to $0.475 \mathrm{M}$ in the Ammonite 8, along with an adequate increase in current led to the isolation of $17.2 \mathrm{~g}(89 \%)$ of product 2 over $20 \mathrm{~h}$. The larger Ammonite 15 reactor, with a $2 \mathrm{~m}$ long channel and reactor volume of 5.0 $\mathrm{mL}$, allows for higher flow rate whilst preserving high conversions. ${ }^{14 \mathrm{~b}}$ At a substrate concentration of $0.30 \mathrm{M}$ and flow rate to $4.0 \mathrm{~mL} \mathrm{~min}^{-1}, 63 \mathrm{~g}$ of the alcohol 2 was obtained over $8.3 \mathrm{~h}$ without additional optimization.

Sustainability metrics provide a useful guide to assess the impact of a reaction or process, and their application is becoming more widespread. ${ }^{17}$ With this in mind we performed a comparative analysis of the electrochemical PMB deprotection with that of other reported deprotections (table 4). ${ }^{17 \mathrm{a}}$ Atom economy (AE) scores are inherently compromised for deprotection reactions, and are largely dependent on the size of the molecule compared to the protecting group. Consequently, for the low molecular weight molecules being compared, mostly scores that raise concern are observed (entries 1-3 and 5). Reaction mass efficiency (RME), which also considers reagents and stoichiometry, can provide a good assessment of the sustainability credentials. Here the electrochemical deprotection scores favorably (entries 1 and 2), as only a small amount of electrolyte is required to facilitate the reaction. RME can be improved by electrolyte recovery. For the other deprotection methods RME values are lower due to the requirement for excess reagents or additives (entries 3-5), and use of metals with potential future supply issues is also of concern (entries 3 and 5). ${ }^{17 \mathrm{a}}$ Finally, solvent selection is highly influential on the impact of a reaction as it is often the largest single component added, ${ }^{17 \mathrm{a}}$ and replacement of chlorinated solvent or $\mathrm{MeCN}$ with $\mathrm{MeOH}$ is advantageous.

There are many metrics available to assess sustainability credentials, and the ones used here focus on the reactions and do not include work-up and purification steps because these have not been optimized. However, reagentless processes such as this electrochemical methodology can help to reduce the process mass intensity (PMI) through further process development by simplifying work-ups as excess reagent or byproduct does not need to be removed. ${ }^{18}$

In summary, an electrochemical deprotection of PMB ethers in a microflow cell has been described, and demonstrated for a range of substrates. Furthermore, the ease of scale up in a laboratory context has been highlighted, with the Ammonite 8 reactor producing $17.2 \mathrm{~g}$ of alcohol 2 in $20 \mathrm{~h}$, and the Ammonite 15 yielding $63.0 \mathrm{~g}$ (consuming $153.8 \mathrm{~g}$ of starting material) in 8.3 h. Finally, sustainability metrics were compared with those of other reported procedures for PMB deprotection. In particular, the RME was favorable and the use of preferred solvents makes the described PMB deprotection a useful option on a variety of scales. 
1

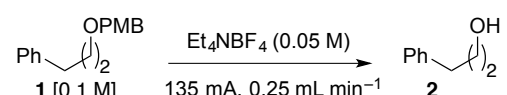

2

$$
1[0.3 \mathrm{M}] \underset{6.0 \mathrm{~A}, 4.0 \mathrm{~mL} \mathrm{~min}-1}{\stackrel{\mathrm{Et}_{4} \mathrm{NBF}_{4}(0.05 \mathrm{M})}{\longrightarrow}} \mathbf{2}
$$

$3^{6 c}$

$$
\text { OMBO, }
$$

$4^{8 e}$

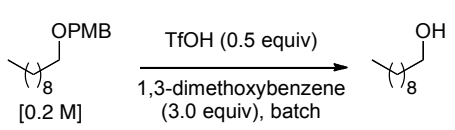

$5^{8 f}$

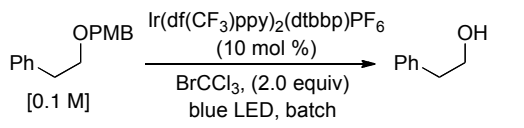

92

77

8

98

Key: $=$ Desired $/$ no problems. $\bigcirc=$ Problematic. $\bigcirc=$ Undesired $/$ very problematic $/$ hazardous. ${ }^{\text {a }}$ RME value taking into consideration recovery of $\mathrm{Et}_{4} \mathrm{NBF}_{4}$ by precipitation from the crude reaction mixture.

\section{ASSOCIATED CONTENT}

\section{Supporting Information}

Experimental details and procedures, compound characterization data, description of flow electrolysis cells, cyclic voltammetry, expanded metrics tables and copies of ${ }^{1} \mathrm{H}$ and ${ }^{13} \mathrm{C}$ NMR spectra for all new compounds.

The Supporting Information is available free of charge on the ACS Publications website.

SI file is attached as pdf

\section{AUTHOR INFORMATION}

\section{Corresponding Author}

*rcb1@soton.ac.uk

\section{Author Contributions}

The manuscript was written through contributions of all authors.

\section{ACKNOWLEDGMENT}

The authors acknowledge financial support from EPSRC (EP/L003325/1 and EP/K039466/1). This work was also supported by Eli Lilly and Company through the Lilly Research Award Program (LRAP).

\section{REFERENCES}

(1) (a) Kocieński, P. J.; Protecting Groups, $3^{\text {rd }}$ ed. Thieme, Stuttgart, 2005. (b) Wuts, P. G. M.; The Role of Protecting Groups. In Greene's Protective Groups in Organic Synthesis, $5^{\text {th }}$ ed. John Wiley \& Sons, New York, 2014, pp. 1-16. (c) Schelhaas, M.; Waldmann, H. Angew. Chem. Int. Edit. 1996, 35, 2056.

(2) For reviews: (a) Saicic, R. N. Tetrahedron 2014, 70, 8183. (b) Hoffmann, R. W.; Handbook of Green Chemistry, Wiley-VCH Verlag GmbH \& Co. KGaA, 2010. (c) Young, I. S.; Baran, P. S.; Nat Chem 2009, 1, 193. (d) Newhouse, T.; Baran, P. S.; Hoffmann, R. W.; Chem. Soc. Rev. 2009, 38, 3010. (e) Hoffmann, R. W. Synthesis 2006, 3531.

(3) For selected examples in natural product synthesis: (a) Stambulyan, H.; Minehan, T. G. Org. Biomol. Chem. 2016, 14, 8728. (b) Yan, X. X.; Hu, X. D. J. Org. Chem. 2014, 79, 5282. (c) Morales, C. P.; Catalán, J.; Domingo, V.; González Delgado, J. A. G.; Dobado, J. A.; Herrador, M. M.; Quílez del Moral, J. F. Q.; Barrero, A. F. J. Org.
Chem. 2011, 76, 2494. (d) Cecil, A. R. L.; Brown, R. C. D. Org. Lett. 2002, 4, 3715 .

(4) For selected examples in natural product synthesis: (a) $\mathrm{H}$. Fuwa, K. Sakamoto, T. Muto and M. Sasaki, Tetrahedron 2015, 71, 6369. (b) Mukaiyama, T.; Shiina, I.; Iwadare, H.; Saitoh, M.; Nishimura, T.; Ohkawa, N.; Sakoh, H.; Nishimura, K.; Tani, Y.; Hasegawa, M.; Yamada, K.; Saitoh, K. Chem. Eur. J. 1999, 5, 121. (c) Kocienski, P. J.; Brown, R. C. D.; Pommier, A.; Procter, M.; Schmidt, B., J. Chem. Soc. Perkin Trans. 1 1998, 9. (d) Horita, K.; Oikawa, Y.; Nagato, S.; Yonemitsu, O. Tetrahedron Lett. 1988, 29, 5143.

(5) For a recent review of PMB esters: (a) Howard, K. T.; Chisholm, J. D. Org. Prep. Proced. Int. 2016, 48, 1. For selected examples of PMB protection of nitrogen compounds: (b) Owen, D. R.; Bull, D. J.; Bunnage, M. E.; Glossop, M. S.; Maguire, R. J.; Strang, R. S.; Bioorg. Med. Chem. Lett. 2010, 20, 92. (c) Bartoli, G.; Bartolacci, M.; Cortese, M.; Marcantoni, E.; Massaccesi, M.; Pela, R.; Sambri, L. Eur. J. Org. Chem. 2004, 2359. (d) Chern, C. Y.; Huang, Y. P.; Kan, W. M. Tetrahedron Lett. 2003, 44, 1039.

(6) (a) Oikawa, Y.; Yoshioka, T.; Yonemitsu, O.; Tetrahedron Lett. 1982, 23, 885. (b) Classon, B.; Garegg, P. J.; Samuelsson, B. Acta Chem. Scand. Ser. B 1984, 38, 419. (c) Johansson, R.; Samuelsson, B. J. Chem. Soc. Perkin Trans. 1 1984, 2371.

(7) (a) Wuts, P. G. M.; Protection of the Hydroxyl Group, Including 1,2- and 1,3-Diols. In Greene's Protective Groups in Organic Synthesis, $5^{\text {th }}$ Ed. John Wiley \& Sons, New York, 2014, pp. 17-471. For a review: (b) Weissman, S. A.; Zewge, D. Tetrahedron, 2005, 61, 7833.

(8) (a) Kern, N.; Dombray, T.; Blanc, A.; Weibel, J.-M.; Pale, P. J. Org. Chem. 2012, 77, 9227. (b) Liu, L.; Floreancig, P. E. Org. Lett. 2010, 12, 4686. (c) Sharma, G. V. M.; Reddy, C. G.; Krishna, P. R. J. Org. Chem. 2003, 68, 4574. (d) Hinklin, R. J.; Kiessling, L. L. Org. Lett. 2002, 4, 1131. (e) Jung, M. E.; Koch, P. Tetrahedron Lett. 2011, 52, 6051. (f) Tucker, J. W.; Narayanam, J. M. R.; Shah, P. S.; Stephenson, C. R. J. Chem. Commun. 2011, 47, 5040.

(9) Oikawa, Y.; Tanaka, T.; Horita, K.; Yonemitsu, O. Tetrahedron Lett. 1984, 25, 5397.

(10) (a) Organic Electrochemistry, 4th ed.; Lund, H.; Hammerich, O., Marcel Dekker, New York, 2001. (b) Steckhan, E.; Arns, T.; Heineman, W. R.; Hilt, G.; Hoormann, D.; Jörissen, J.; Kröner, L.; Lewall, B.; Pütter, H. Chemosphere 2001, 43, 63. (c) Hayashi, R.; Shimizu, A.; Yoshida, J.-i. J. Am. Chem. Soc. 2016, 138, 8400.

(11) (a) Weinreb, S. M.; Epling, G. A.; Comi, R.; Reitano, M. J Org. Chem. 1975, 40, 1356. (b) Schmidt, W.; Steckhan, E. Angew. Chem. Int. Ed. 1978, 17, 673.

(12) Reviews: (a) Watts, K.; Baker A.; Wirth, T. J. Flow Chem., 2014, 4, 2. (b) Yoshida. J. Chem. Commun. 2005, 4509. Selected examples: (c) Arai, T.; Tateno, H.; Nakabayashi, K.; Kashiwagi, T.; 
Atobe, M. Chem. Commun. 2015, 51, 4891. (d) Arai, K.; Wirth, T. Org. Process Res. Dev. 2014, 18, 1377. (e) Gütz, C.; Bänziger, M.; Bucher, C.; Galvão, T. R.; Waldvogel, S. R. Org. Process Res. Dev. 2015, 19, 1428. (e) Attour, A.; Dirrenberger, P.; Rode, S.; Ziogas, A.; Matlosz M.; Lapique, F. Chem. Eng. Sci. 2011, 66, 480.

(13) (a) Horcajada, R; Okajima, M.; Suga, S.; Yoshida, J. Chem. Commun. 2005, 1303-1305. (b) Horii, D.; Atobe, M.; Fuchigami, T.; Marken, F. J. Electrochem. Soc. 2006, 153, D143-D147.

(14) (a) Green, R. A.; Brown, R. C. D.; Pletcher, D.; Harji, B. Electrochem. Commun. 2016, 73, 63. (b) Green, R. A.; Brown, R. C. D.; Pletcher, D.; Harji, B. Org. Process Res. Dev. 2015, 19, 1424. (c) Kuleshova, J.; Hill-Cousins, J. T.; Birkin, P. R.; Brown, R. C. D.; Pletcher, D.; Underwood, T. J., Electrochim. Acta 2012, 69, 197. (d)
Kuleshova, J.; Hill-Cousins, J. T.; Birkin, P. R.; Brown, R. C. D.; Pletcher, D.; Underwood, T. J. Electrochim. Acta 2011, 56, 4322.

(15) (a) Green, R. A.; Brown, R. C. D.; Pletcher, D. J. Flow Chem. 2016, 6, 191. (b) Green, R. A.; Brown, R. C. D.; Pletcher, D. J. Flow Chem. 2015, 5, 31 .

(16) see Supporting Information for details of metric calculations.

(17) (a) McElroy, C. R.; Constantinou, A.; Jones, L. C.; Summerton, L.; Clark, J. H. Green Chem. 2015, 17, 3111. (b) Dach, R.; Song, J. J.; Roschangar, F.; Samstag, W.; Senanayake, C. H. Org. Process Res. Dev. 2012, 16, 1697. (c) Constable, D. J. C.; Curzons, A. D.; Cunningham, V. L. Green Chem. 2002, 4, 521.

(18) Process mass intensity is defined as the total mass in a process or step divided by the mass of the product. For more detailed description of the sustainability metrics see Supporting Information. 